\title{
GERMPLASM EVALUATION OF TOMATILLO \\ (PHYSALIS IXOCARPA BROT.) CROPPED UNDER \\ ONTARIO, CANADA AND CHAPINGO, MEXICO ENVIRONMENTAL CONDITIONS
}

\author{
Juan MULATO-BRITO, Aureliano PEÑA-LOMELÍ \\ Departamento de Fitotecnia, Universidad Autónoma Chapingo \\ Chapingo, Edo. de México, C.P. 56230, México
}

\begin{abstract}
Summary
Evaluation of five tomatillo Mexican landraces including altogether 13 accessions was performed under environmental conditions of Ontario, Canada and Chapingo in central Mexico. The measured traits were: beginning of flowering and harvest, total number of harvested fruits and the yield. Number of days to flowering or fruiting was counted from the date of planting. In both localities accessions 1 and 3 of the Rendidora landrace as well as the accession 1 of the Manzano landrace were the earliest and the highest yielding. In Chapingo the accession 1 of the Rendidora landrace gave the yield of fruits almost $4 \mathrm{~kg} \cdot \mathrm{m}^{-2}$, in Elora, Canada the same accession was also the best and yielded almost 3 $\mathrm{kg} \cdot \mathrm{m}^{-2}$. In general, all accessions were earlier in Elora than in Chapingo; yield in both localities was in general similar except the landrace Milpero obviously poorly suited to Canadian environment. Tomatillo may be considered as a promising new crop for Ontario, Canada agriculture. Yield was correlated negatively, in a significant way, with the number of days to flowering and harvest, it means that the development of early, highly productive varieties by artificial selection is feasible.
\end{abstract}

key words: Tomatillo, Physalis ixocarpa, germplasm evaluation

\section{INTRODUCTION}

Farmers of different agricultural regions of North America, especially small growers, have recently been looking for new and unusual crops to diversify their agricultural operations. The introduction of these new crops is focused on finding or creating plants with superior taste, appearance or human cultural requirements (McCain 1991).

Tomatillo (Physalis ixocarpa Brot.) was domesticated and has been cultivated in Mexico since pre-Columbian times (Menzel 1951, Bukasov 1963). This species shows in Mexico, a high amount of genetic diversity and some landraces can be found growing wild along the Pacific Coast from California to

Corresponding aothor:

e-mail: gentlejubri@hotmail.com

(C) Copyright by RIVC 
Nicaragua (Menzel 1951). Several landraces are encountered also among cultivated tomatillo plants in central and western Mexico (Peña-Lomeli \& MárquezSánchez 1990). Tomatillo belongs to the genus Physalis with approximately 80 species spread throughout temperate and tropical areas of the Americas, but some are located in Australia, East Asia, India, New Zealand and South Africa (Menzel 1951). Only three of these species are cultivated, Physalis peruviana in Australia and New Zealand, Physalis pruinosa in North America and Physalis ixocarpa in México (Jenkins 1948).

In 1985, the University of Chapingo, in central Mexico, started a tomatillo breeding program. Currently, the University of Chapingo's Gene Bank owns more than 100 accessions from different States of Mexico. Such germplasm reserve could be considered adequate to make some efforts to try to introduce this crop to Canada, but first, it seemed important to evaluate the adaptation of some tomatillo genotypes to Ontario environmental conditions. Tomatillo $(P$. ixocarpa Brot.) life cycle is short. It takes 12 to 14 weeks in the field from planting to harvest, if seeding is direct or 8 to 10 weeks if transplanted (MulatoBrito et al. 1985), and thus, it may be a good option to Ontario agriculture due to the short growth season present in this area. Such a short life cycle of tomatillo has allowed it to be introduced in some other countries such as: Austria, France, Hungary, Italy, Poland, Russia, Spain, Turkey and United States (Medvedev 1958, Cuartero et al. 1983, Peron et al. 1989, Jankiewicz \& Borkowski 1990, Moriconi et al. 1990, Porcelli \& Proto 1991, Cantwell et al. 1992, Abak et al. 1994). Nevertheless, the introduction of a new crop into practical agriculture is not an easy task. A new crop, never previously grown or domesticated, needs to be adapted to the specific environmental conditions prevalent in the place where such a new crop is going to be introduced. The new cultivars or genotypes will then need to be developed with the appropriate agronomical characteristics, good productivity and resistance for local pests and diseases (Bertram 1991, Rexen 1993).

Thus, this investigation has the following objectives: a) to evaluate the performance and adaptation of several Mexican tomatillo genotypes in the conditions of Ontario, Canada; b) to compare the behavior of the same germplasm to the conditions of Chapingo, Mexico; c) to select the best adapted genotypes for further cropping under local environmental conditions. Research is based on the hypothesis that tomatillo has a short life cycle which is an advantage for being successfully grown under Ontario, Canada environmental conditions.

\section{MATERIALS AND METHODS}

The experiment was established in Elora, Ontario, Canada (1996) and in Chapingo, Mexico (1998). Five different Mexican landraces of tomatillo were evaluated: Manzano, Milpero, Rendidora, Salamanca and Tamazula. One accession of the Manzano landrace and three accessions of the other ones (a total of 13 accessions) were selected and established in the field, from transplants, in a complete randomized block design with three replicates. The experimental unit 
was 3 rows, $4.5 \mathrm{~m} \mathrm{x} 1.0 \mathrm{~m}$, with 10 plants in each row. All data were taken, per plant, in the central row. Soil type in Canada was clay and most of the tomatillo life cycle was under intermittent inundation, fertilization was not applied either, but tomatillo was cropped after cultivating beans in the previous cycle. The experiment began on the first week of May and ended early on the third week of September when the first frost arrived, neither pests nor diseases did affect crop development. In Chapingo soil type was loamy, the crop was under irrigation and fertilization (160-80-00), some local pest and diseases were present but did not affect too much yield, growth season lasting was not critical. The measured traits were: beginning of flowering (opening of flower $1=$ ofl 1 , opening of flower $5=\mathrm{ofl} 15$ ), beginning of harvest (fruit 1 harvest=fr $1 \mathrm{~h}$, fruit 5 harvest $=\mathrm{fr} 5 \mathrm{~h}$ ), total number of harvested fruits per plant (tnfr), average weight per fruit (awpfr), yield (y). The values ofl, ofl5, frlh and fr5h were counted in days from planting. Data were analyzed in each locality, by using a nested factor design where accessions are nested within landraces (Montgomery 1991, Kuehl 1994). Some missing data were obtained, resulting in an unbalanced design. To overcome this problem, a Sas procedure using General Linear Models (Sas 1985) was run. A combined analysis was performed by joining data for both localities.

\section{RESULTS}

\section{Elora, Ontario, Canada.}

With the anova analysis there were shown significant differences in almost all traits that were evaluated. These differences were present among landraces and among accessions within landraces (except for the factor accessions within landrace on the frlh trait).

Rendidora, Manzano and Salamanca landraces were the earliest considering ofl1, Tamazula and Milpero were the latest (Table 1). When analyzing ofl5, Manzano landrace seems to be the earliest, Rendidora and Salamanca intermediate, Milpero and Tamazula the latest. When analyzing fr $1 \mathrm{~h}$ and fr5h, Manzano and Rendidora landraces are likely the earliest, Salamanca and Tamazula intermediate and Milpero the latest. Manzano, Rendidora and Tamazula landraces produced the highest total number of fruits per plant (tnfr), followed by Salamanca and Milpero (Table 1) a similar trend was observed for the average weight per fruit (awpfr), however Milpero landrace showed a very low awpfr value. Manzano landrace yielded approximately $2.7 \mathrm{~kg} \cdot \mathrm{m}^{-2}$, while Rendidora landrace yielded a little bit more than $2.4 \mathrm{~kg} \cdot \mathrm{m}^{-2}$ and Milpero plants gave very low yield. 
Table 1. Mean comparison among tomatillo landraces on seven traits. Elora, Ontario, Canada

\begin{tabular}{lccccccc}
\hline Landrace & ofl1 & ofl5 & fr1h & fr5h & tnfr & $\begin{array}{c}\text { awpfr } \\
(\mathrm{g})\end{array}$ & $\begin{array}{c}\text { yield } \\
\left(\mathrm{kg} \cdot \mathrm{m}^{-2}\right)\end{array}$ \\
\hline Rendidora & $45.3 \mathrm{~b}$ & $71.8 \mathrm{bc}$ & $91.1 \mathrm{bc}$ & $112.4 \mathrm{c}$ & $36.3 \mathrm{a}$ & $31.1 \mathrm{a}$ & $2.42 \mathrm{a}$ \\
Salamanca & $49.1 \mathrm{~b}$ & $76.9 \mathrm{ab}$ & $96.7 \mathrm{abc}$ & $118.7 \mathrm{ab}$ & $21.8 \mathrm{~b}$ & $28.2 \mathrm{a}$ & $1.34 \mathrm{~b}$ \\
Tamazula & $56.0 \mathrm{a}$ & $80.0 \mathrm{a}$ & $97.7 \mathrm{ab}$ & $114.4 \mathrm{bc}$ & $33.9 \mathrm{ab}$ & $16.7 \mathrm{~b}$ & $1.17 \mathrm{~b}$ \\
Milpero & $58.3 \mathrm{a}$ & $79.9 \mathrm{a}$ & $103.2 \mathrm{a}$ & $122.6 \mathrm{a}$ & $21.6 \mathrm{~b}$ & $9.1 \mathrm{c}$ & $0.42 \mathrm{c}$ \\
Manzano & $47.7 \mathrm{~b}$ & $68.3 \mathrm{c}$ & $88.0 \mathrm{c}$ & $109.3 \mathrm{c}$ & $39.3 \mathrm{a}$ & $30.7 \mathrm{a}$ & $2.69 \mathrm{a}$ \\
$\mathrm{HSD}_{0.05}$ & 4.67 & 5.56 & 8.92 & 5.84 & 14.47 & 5.00 & 0.58 \\
\hline
\end{tabular}

Note: Means followed by the same letter do not differ significantly according to Tukey-test

Comparison of tomatillo accessions within landraces is shown in Table 2. Rendidora landrace accessions 1, 3 and Manzano landrace accession 1 were, in general, the earliest for flowering initiation (ofl1,ofl5) and fruit harvest (fr1h,fr5h) dates, although Salamanca landrace accession 2 showed also early flowering (ofl1, ofl5), Rendidora accessions 1 and 3 and Manzano accession 1 were also highest yielding. The other accessions within landraces did not show any significant differences concerning the earliness. Regarding to tnfr and awpfr traits, Tamazula landrace accession 3, produced bigger and much less fruits per plant than accession 2. There were, however, no significant differences in the yield among the three accesions of Tamazula.

Table 2. Mean comparison among accessions within tomatillo landraces on seven traits. Elora, Ontario, Canadá

\begin{tabular}{ccccccccc}
\hline Landrace & Accession & ofl1 & ofl5 & fr1h & fr5h & tnfr & $\begin{array}{c}\text { awpfr } \\
(\mathrm{g})\end{array}$ & $\begin{array}{c}\text { yield } \\
\left(\mathrm{kg} \cdot \mathrm{m}^{-2}\right)\end{array}$ \\
\hline Rendidora & 1 & $43.7 \mathrm{~b}$ & $67.6 \mathrm{~b}$ & $87.3 \mathrm{~b}$ & $108.0 \mathrm{~b}$ & $45.3 \mathrm{a}$ & $29.6 \mathrm{a}$ & $2.98 \mathrm{a}$ \\
& 2 & $50.7 \mathrm{a}$ & $78.3 \mathrm{a}$ & $99.5 \mathrm{a}$ & $120.0 \mathrm{a}$ & $23.3 \mathrm{~b}$ & $32.8 \mathrm{a}$ & $1.51 \mathrm{~b}$ \\
& 3 & $41.7 \mathrm{~b}$ & $70.0 \mathrm{~b}$ & $89.3 \mathrm{ab}$ & $109.3 \mathrm{~b}$ & $40.3 \mathrm{ab}$ & $31.0 \mathrm{a}$ & $2.78 \mathrm{a}$ \\
& $\mathrm{HSD}_{0.05}$ & 5.79 & 6.89 & 10.93 & 7.24 & 17.94 & 6.20 & 0.72 \\
\hline Salamanca & 1 & $48.7 \mathrm{ab}$ & $78.3 \mathrm{ab}$ & $98.0 \mathrm{a}$ & $119.3 \mathrm{a}$ & $19.0 \mathrm{a}$ & $30.0 \mathrm{a}$ & $1.26 \mathrm{a}$ \\
& 2 & $45.0 \mathrm{~b}$ & $72.0 \mathrm{~b}$ & $92.0 \mathrm{a}$ & $118.3 \mathrm{a}$ & $21.7 \mathrm{a}$ & $29.7 \mathrm{a}$ & $1.43 \mathrm{a}$ \\
& 3 & $53.7 \mathrm{a}$ & $80.3 \mathrm{a}$ & $100.0 \mathrm{a}$ & $118.3 \mathrm{a}$ & $24.7 \mathrm{a}$ & $24.8 \mathrm{a}$ & $1.32 \mathrm{a}$ \\
& $\mathrm{HSD}_{0.05}$ & 5.79 & 6.89 & 10.93 & 7.24 & 17.94 & 6.20 & 0.72 \\
\hline Tamazula & 1 & $52.3 \mathrm{a}$ & $79.7 \mathrm{a}$ & $95.7 \mathrm{a}$ & $115.7 \mathrm{a}$ & $31.0 \mathrm{~b}$ & $11.9 \mathrm{~b}$ & $0.85 \mathrm{a}$ \\
& 2 & $58.0 \mathrm{a}$ & $80.3 \mathrm{a}$ & $97.7 \mathrm{a}$ & $111.0 \mathrm{a}$ & $49.0 \mathrm{a}$ & $13.8 \mathrm{~b}$ & $1.49 \mathrm{a}$ \\
& 3 & $57.7 \mathrm{a}$ & $80.0 \mathrm{a}$ & $99.7 \mathrm{a}$ & $116.7 \mathrm{a}$ & $21.7 \mathrm{~b}$ & $24.2 \mathrm{a}$ & $1.16 \mathrm{a}$ \\
& $\mathrm{HSD}_{0.05}$ & 5.79 & 6.89 & 10.93 & 7.24 & 17.94 & 6.20 & 0.72 \\
\hline Milpero & 1 & $61.3 \mathrm{a}$ & $83.3 \mathrm{a}$ & $105.0 \mathrm{a}$ & $123.3 \mathrm{a}$ & $21.3 \mathrm{a}$ & $8.7 \mathrm{a}$ & $0.42 \mathrm{a}$ \\
& 2 & $55.7 \mathrm{a}$ & $77.3 \mathrm{a}$ & $99.3 \mathrm{a}$ & $122.7 \mathrm{a}$ & $22.3 \mathrm{a}$ & $9.5 \mathrm{a}$ & $0.42 \mathrm{a}$ \\
& 3 & $58.0 \mathrm{a}$ & $79.0 \mathrm{a}$ & $105.3 \mathrm{a}$ & $121.7 \mathrm{a}$ & $21.0 \mathrm{a}$ & $9.1 \mathrm{a}$ & $0.42 \mathrm{a}$ \\
& $\mathrm{HSD}_{0.05}$ & 5.79 & 6.89 & 10.93 & 7.24 & 17.94 & 6.20 & 0.72 \\
\hline Manzano & 1 & 47.7 & 68.3 & 88.0 & 109.3 & 39.3 & 30.7 & 2.69 \\
\hline
\end{tabular}

Note: See Table 1 


\section{Chapingo, Mexico, Mexico.}

With the anova analysis it was shown that highly significant differences $(\mathrm{P}<0.01)$ are occurring among landraces in all traits evaluated. Rendidora, Manzano and Salamanca landraces were the earliest (ofl1, ofl5) but Tamazula and Milpero landraces were the latest (Table 3). Regarding to fr $1 \mathrm{~h}$ and fr5h, Manzano and Rendidora landraces were the earliest while the other ones were in general later.

Table 3. Comparison of tomatillo landraces by means of seven traits. Chapingo, Mexico

\begin{tabular}{lccccccc}
\hline Landrace & ofl1 & ofl5 & fr1h & fr5h & tnfr & $\begin{array}{c}\text { awpfr } \\
(\mathrm{g})\end{array}$ & $\begin{array}{c}\text { yield } \\
\left(\mathrm{kg} \cdot \mathrm{m}^{-2}\right)\end{array}$ \\
\hline Rendidora & $56.0 \mathrm{~b}$ & $74.7 \mathrm{c}$ & $101.4 \mathrm{~b}$ & $113.6 \mathrm{ab}$ & $67.8 \mathrm{ab}$ & $16.1 \mathrm{a}$ & $2.54 \mathrm{a}$ \\
Salamanca & $58.8 \mathrm{~b}$ & $77.2 \mathrm{bc}$ & $109.0 \mathrm{a}$ & $121.0 \mathrm{a}$ & $43.4 \mathrm{~b}$ & $13.4 \mathrm{a}$ & $1.25 \mathrm{~b}$ \\
Tamazula & $63.6 \mathrm{a}$ & $80.4 \mathrm{a}$ & $107.3 \mathrm{ab}$ & $118.3 \mathrm{ab}$ & $63.2 \mathrm{ab}$ & $9.6 \mathrm{~b}$ & $1.31 \mathrm{~b}$ \\
Milpero & $65.3 \mathrm{a}$ & $80.1 \mathrm{ab}$ & $110.8 \mathrm{a}$ & $121.0 \mathrm{a}$ & $93.7 \mathrm{a}$ & $5.9 \mathrm{c}$ & $1.23 \mathrm{~b}$ \\
Manzano & $57.3 \mathrm{~b}$ & $76.0 \mathrm{c}$ & $102.7 \mathrm{~b}$ & $109.7 \mathrm{~b}$ & $63.0 \mathrm{ab}$ & $15.9 \mathrm{a}$ & $2.24 \mathrm{a}$ \\
HSD $_{0.05}$ & 3.36 & 2.97 & 6.11 & 9.28 & 33.53 & 3.58 & 0.91 \\
\hline
\end{tabular}

Note: See Table 1

When tnfr is analyzed, tomatillo germplasm can be divided in 3 groups: the first one is represented by Milpero landrace which showed the highest number of fruits per plant, the second one is formed by Rendidora, Tamazula and Manzano landraces with intermediate tnfr and the third one is constituted by Salamanca landrace with the lowest tnfr. Regarding to awpfr, the landraces Rendidora, Manzano and Salamanca produced bigger fruits than Tamazula and Milpero landraces. Based on yield response, Rendidora and Manzano landraces yielded the highest. Rendidora landrace produced a little bit more than $2.5 \mathrm{~kg} \cdot \mathrm{m}^{-2}$ and Manzano landrace produced as much as $2.2 \mathrm{~kg} \cdot \mathrm{m}^{-2}$. Salamanca and Tamazula landraces yielded also, almost the same as in Elora but Milpero landrace produced 3 times the yield obtained in Elora.

In general, the performance of all tomatillo accessions within landraces was quite similar (Table 4); nevertheless, the factor accessions within landraces was highly significant $(\mathrm{P}<0.01)$ on ofl1, tnfr and y traits, but non significant on the remaining ones $(\mathrm{P}>0.05)$.

Rendidora accessions 1 and 3 showed the lowest fr $1 \mathrm{~h}$, high tnfr, and the highest awpfr and yield. Yield of Rendidora accession 1 was almost $4 \mathrm{~kg} \cdot \mathrm{m}^{-2}$. Manzano accession 1 also was relatively early and productive $\left(2.23 \mathrm{~kg} \cdot \mathrm{m}^{-2}\right)$. Salamanca accessions 1 and 2 were the earliest based on ofl 1 but this earliness is only apparent because the other reproductive traits (ofl5, fr $1 \mathrm{~h}$, fr $5 \mathrm{~h}$ ) did not show any significant difference. Tamazula landrace 1 showed lower awpfr and lower $y$ than two other accessions of this landrace. Tamazula accession 2 gave relatively high yield $\left(1.87 \mathrm{~kg} \cdot \mathrm{m}^{-2}\right)$. 
Table 4. Mean comparison among accessions within tomatillo landraces on seven traits, Chapingo, Mexico

\begin{tabular}{lcccccccc}
\hline Landrace & Accession & ofl & ofl5 & frlh & fr5h & tnfr & $\begin{array}{c}\text { awpfr } \\
(\mathrm{g})\end{array}$ & $\begin{array}{c}\text { yield } \\
\left(\mathrm{kg} \cdot \mathrm{m}^{-2}\right)\end{array}$ \\
\hline Rendidora & 1 & $56.0 \mathrm{a}$ & $74.0 \mathrm{a}$ & $98.0 \mathrm{~b}$ & $109.0 \mathrm{a}$ & $95.7 \mathrm{a}$ & $18.1 \mathrm{a}$ & $3.87 \mathrm{a}$ \\
& 2 & $56.0 \mathrm{a}$ & $75.0 \mathrm{a}$ & $106.0 \mathrm{a}$ & $120.0 \mathrm{a}$ & $35.3 \mathrm{~b}$ & $12.2 \mathrm{~b}$ & $0.95 \mathrm{~b}$ \\
& 3 & $56.0 \mathrm{a}$ & $75.0 \mathrm{a}$ & $99.0 \mathrm{ab}$ & $110.0 \mathrm{a}$ & $72.3 \mathrm{ab}$ & $18.0 \mathrm{a}$ & $2.79 \mathrm{a}$ \\
& HSD $_{0.05}$ & 4.17 & 3.68 & 7.58 & 11.5 & 41.58 & 4.44 & 1.12 \\
\hline Salamanca & 1 & $56.0 \mathrm{~b}$ & $76.0 \mathrm{a}$ & $108.0 \mathrm{a}$ & $120.0 \mathrm{a}$ & $41.3 \mathrm{a}$ & $14.0 \mathrm{a}$ & $1.29 \mathrm{a}$ \\
& 2 & $56.0 \mathrm{~b}$ & $76.0 \mathrm{a}$ & $108.0 \mathrm{a}$ & $120.0 \mathrm{a}$ & $29.0 \mathrm{a}$ & $12.0 \mathrm{a}$ & $0.89 \mathrm{a}$ \\
& 3 & $64.0 \mathrm{a}$ & $79.0 \mathrm{a}$ & $110.0 \mathrm{a}$ & $122.0 \mathrm{a}$ & $60.0 \mathrm{a}$ & $14.1 \mathrm{a}$ & $1.58 \mathrm{a}$ \\
& $\mathrm{HSD}_{0.05}$ & 4.17 & 3.68 & 7.58 & 11.5 & 41.58 & 4.44 & 1.12 \\
\hline Tamazula & 1 & $63.0 \mathrm{a}$ & $79.0 \mathrm{a}$ & $108.0 \mathrm{a}$ & $120.0 \mathrm{a}$ & $57.0 \mathrm{a}$ & $5.5 \mathrm{~b}$ & $0.71 \mathrm{~b}$ \\
& 2 & $64.0 \mathrm{a}$ & $81.0 \mathrm{a}$ & $107.0 \mathrm{a}$ & $114.0 \mathrm{a}$ & $84.0 \mathrm{a}$ & $10.2 \mathrm{a}$ & $1.87 \mathrm{a}$ \\
& 3 & $63.0 \mathrm{a}$ & $80.0 \mathrm{a}$ & $106.0 \mathrm{a}$ & $120.0 \mathrm{a}$ & $48.7 \mathrm{a}$ & $13.1 \mathrm{a}$ & $1.36 \mathrm{ab}$ \\
& $\mathrm{HSD}_{0.05}$ & 4.17 & 3.68 & 7.58 & 11.5 & 41.58 & 4.44 & 1.12 \\
\hline Milpero & 1 & $65.0 \mathrm{a}$ & $79.0 \mathrm{a}$ & $108.0 \mathrm{a}$ & $120.0 \mathrm{a}$ & $73.0 \mathrm{a}$ & $6.3 \mathrm{a}$ & $1.02 \mathrm{a}$ \\
& 2 & $64.0 \mathrm{a}$ & $79.0 \mathrm{a}$ & $112.0 \mathrm{a}$ & $117.0 \mathrm{a}$ & $96.3 \mathrm{a}$ & $6.2 \mathrm{a}$ & $1.33 \mathrm{a}$ \\
& 3 & $65.0 \mathrm{a}$ & $81.0 \mathrm{a}$ & $111.0 \mathrm{a}$ & $125.0 \mathrm{a}$ & $111.7 \mathrm{a}$ & $5.3 \mathrm{a}$ & $1.33 \mathrm{a}$ \\
& $\mathrm{HSD}_{0.05}$ & 4.17 & 3.68 & 7.58 & 11.5 & 41.58 & 4.44 & 1.12 \\
\hline Manzano & 1 & 57.0 & 76.0 & 102.0 & 109.0 & 63.0 & 15.9 & 2.23 \\
\hline
\end{tabular}

Note: See Table 1.

\section{Combined analysis}

With the anova analysis very significant differences $(\mathrm{P}<0.01)$ between localities were found for ofl1, fr1h, tnfr, but the differences for ofl5, fr5h and y were not significant (Table 5). For Elora locality (Canada) the traits ofl1, fr $1 \mathrm{~h}$, and tnfr had lower values and awprf on the contrary higher than for Chapingo, the other values for these two localities, as mentioned, did not differ statistically.

Table 5. Means for 13 tomatillo accessions: comparison between two localities. Combined analyis. Elora, Ontario, Canadá - 1996; Chapingo, México - 1998

\begin{tabular}{lccccccc}
\hline Locality & ofl1 & of15 & fr1h & fr5h & tnfr & $\begin{array}{c}\text { awpfr } \\
(\mathrm{g})\end{array}$ & $\begin{array}{c}\text { yield } \\
\left(\mathrm{kg} \cdot \mathrm{m}^{-2}\right)\end{array}$ \\
\hline Elora & $51.9 \mathrm{~b}$ & $76.5 \mathrm{a}$ & $96.6 \mathrm{~b}$ & $116.4 \mathrm{a}$ & $29.2 \mathrm{~b}$ & $22.0 \mathrm{a}$ & $1.44 \mathrm{a}$ \\
Chapingo & $60.6 \mathrm{a}$ & $78.0 \mathrm{a}$ & $106.8 \mathrm{a}$ & $117.8 \mathrm{a}$ & $66.7 \mathrm{a}$ & $11.6 \mathrm{~b}$ & $1.63 \mathrm{a}$ \\
HSD $_{0.05}$ & 1.37 & 2.01 & 3.76 & 2.33 & 3.89 & 1.20 & 0.22 \\
\hline
\end{tabular}

Note: See Table 1

The comparison of mean for landraces and accession within landraces showed the same trend, as in the individual analysis by locality (data not shown). The FxL interaction was non significant in most of traits, which were evaluated, only tnfr, awpfr and y were significant. When analyzing FxL interaction on tnfr (Table 6) it was observed, in general, that all landraces produced a 
lower tnfr in Elora locality. Rendidora and Manzano landraces yielded statistically the same in both localities, besides that in Elora the size of the fruits (awpfr) was bigger than in Chapingo (Tables $5 \& 6$ ).

Table 6. Mean comparison in the locality by landrace interaction on three tomatillo traits. Combined analysis. Elora, Ontario, Canadá-1996; Chapingo, México1998

\begin{tabular}{llccccc}
\hline Trait & Locality & Rendidora & Salamanca & Tamazula & Milpero & Manzano \\
\hline tnfr & Elora & $36.3 \mathrm{~d}$ & $21.8 \mathrm{~d}$ & $33.9 \mathrm{~d}$ & $21.6 \mathrm{~d}$ & $39.3 \mathrm{~cd}$ \\
& Chapingo & $67.7 \mathrm{~b}$ & $43.4 \mathrm{bcd}$ & $63.2 \mathrm{bc}$ & $93.7 \mathrm{a}$ & $63.0 \mathrm{bc}$ \\
& HSD $_{0.05}$ & & & & & 24.62 \\
\hline awpfr & Elora & $31.1 \mathrm{a}$ & $28.2 \mathrm{a}$ & $16.6 \mathrm{~b}$ & $9.1 \mathrm{c}$ & $30.7 \mathrm{a}$ \\
$\mathrm{g})$ & Chapingo & $16.1 \mathrm{~b}$ & $13.4 \mathrm{~b}$ & $9.6 \mathrm{bc}$ & $5.9 \mathrm{c}$ & $15.9 \mathrm{~b}$ \\
& HSD $_{0.05}$ & & & & & 4.14 \\
\hline $\mathrm{y}$ & Elora & $2.42 \mathrm{a}$ & $1.34 \mathrm{~b}$ & $1.17 \mathrm{~b}$ & $0.42 \mathrm{c}$ & $2.69 \mathrm{a}$ \\
$\left(\mathrm{kg} \cdot \mathrm{m}^{-2}\right)$ & Chapingo & $2.54 \mathrm{a}$ & $1.25 \mathrm{~b}$ & $1.31 \mathrm{~b}$ & $1.23 \mathrm{~b}$ & $2.24 \mathrm{a}$ \\
& HSD $_{0.05}$ & & & & & 0.726 \\
\hline
\end{tabular}

Note: See Table 1

\section{Correlation analysis}

Six tomatillo traits such as: ofl1, ofl5, fr1h, fr5h, tnfr, awpfr were correlated with the yield (y). Besides of that the difference between the first two traits (X1) and the difference between the third and fourth ones (X2) were correlated with the yield, also. It was found that the yield was negatively and significantly correlated with the first four traits but X1 and X2 did not show any correlation, while tnfr and awpfr were highly and positively correlated (Table $7)$.

Table 7. Correlation coefficients between the yield (y) and eight tomatillo traits

\begin{tabular}{llllcccccc}
\hline Trait & Locality & ofl1 & ofl5 & fr1h & fr5h & tnfr & awpfr & X1 & X2 \\
\hline \multirow{2}{*}{ y } & Elora & $-0.71^{* *}$ & $-0.80^{* *}$ & $-0.68^{* *}$ & $-0.80^{* *}$ & $0.70^{* *}$ & $0.67^{* *}$ & $0.01 \mathrm{~ns}$ & $0.07 \mathrm{~ns}$ \\
& Chapingo & $-0.30 \mathrm{~ns}$ & $-0.34^{*}$ & $-0.62^{* *}$ & $-0.53^{* *}$ & $0.54^{* *}$ & $0.60^{* *}$ & $0.13 \mathrm{~ns}$ & $-0.07 \mathrm{~ns}$ \\
& Combined & $-0.35^{* *}$ & $-0.57^{* *}$ & $-0.44^{* *}$ & $-0.63^{* *}$ & $0.48^{* *}$ & $0.44^{* *}$ & $0.04 \mathrm{~ns}$ & $-0.05 \mathrm{~ns}$ \\
\hline
\end{tabular}

*** = significant $\mathrm{P}=0.05$ and $\mathrm{P}=0.01$, respectively

$\mathrm{ns}=$ non significant $\mathrm{P}=0.05$

\section{DISCUSSION}

Several Mexican cultivated plants, due to their short vegetation period showed the northward expantion and were accepted in agriculture of countries with severe winter, like USA and Canada. This process is not yet terminated and tomatillo is probably the next example.

As it was mentioned the main purpose of this work was to check if Mexican landraces of tomatillo can be cultivated in Ontario, Canada. The other aim 
was to compare the behavior of the same landraces in two so different climatic and edafic conditions as those of Canada and Central Mexico. Basing on this comparison the suggestions for the future tomatillo breeding program were made.

In Elora, Ontario, Canada the Mazano and Rendidora tomatillo landraces were likely the earliest, while Salamanca and Tamazula were intermediate and Milpero the latest. This is considering flowering and harvest traits. This genetic variability is desirable because it would allow breeders to select for earliness what, in consequence, would allow decreasing costs of production in this crop. Besides that these two landraces produced the greatest number of fruits (tnfr) per plant they had large fruits (high awpfr) and yielded the highest. Milpero landrace yielded the lowest and showed very low average weight per fruit (awpfr). Manzano yielded approximately $2.7 \mathrm{~kg} \cdot \mathrm{m}^{-}$ ${ }^{2}$, while Rendidora yielded a little bit more than $2.4 \mathrm{~kg} \cdot \mathrm{m}^{-2}$. Thus it would be advisable to work with Rendidora and Manzano landraces as germplasm source to breed for receiving early and productive cultivars for Ontario agriculture. The factor accession within landraces, in Canada, allows breeders to add some extra information about proper germplasm to select for any given trait. Rendidora landrace accessions 1 and 3 and Manzano landrace accession 1 were, in general, the earliest and most productive. Regarding to awpfr trait just Tamazula landrace accession 3 showed a highly significant value of 24.2 grams per fruit but this accession was the latest and its yield was not high.

In Chapingo, Mexico the Rendidora and Manzano landraces were analogically as in Elora the earliest while the remaining ones were late. As in Elora, these landraces can be recommended to be used as a germplasm source to breed for earliness. Then, in Chapingo, costs of production could be decreased, also. The trait total number of fruits per plant (tnfr) performed a little bit different than in Elora because in Chapingo, the landrace Milpero produced the highest tnfr and yielded 3 times more than Elora because in mild climate of Mexico its plants were able to complete their life cycle. Rendidora and Manzano landraces yielded a little bit more than $2.5 \mathrm{~kg} \cdot \mathrm{m}^{-2}$ and $2.2 \mathrm{~kg} \cdot \mathrm{m}^{-2}$, respectively, these yields are almost the same like those obtained in Elora. Yield of Rendidora landrace accession 1 was very outstanding since it produced almost $4.0 \mathrm{~kg} \cdot \mathrm{m}^{-2}$, the possible explanation is that this accession has been derived from several cycles of selection for high yield from the original Rendidora landrace. Thus, just Rendidora accessions 1 and 3, and Manzano accession 1, and may be Tamazula accession 2, can be recommended to select for earliness, higher number of fruits, size of fruits and higher yield to develop improved varieties for Central Mexico.

It seems remarkable how similarly particular accessions behaved in Elora and in Chapingo, for instance in both localities Rendidora accessions 1 and 3 exceeded the accession 2 with total number of fruits per plant and the yield, also Tamazula accession 2 exceeded the other two accessions when we take into concideration the same traits. This supports the view that the differences among mentioned accessions have the genetic basis.

The combined analysis showed interesting aspects since in Elora locality the values connected with earliness like ofl1 and frhl were significantly lower than in 
Chapingo locality; however, the yield was almost the same. It means that tomatillo could be considered as an early crop in Elora and this locality is good to cultivate it. Although the number of fruits per plant was lower in Elora but it was recompensed by their higher average weight. This only indicates that just a little breeding work is needed to make tomatillo still more attractive to local farmers of Ontario, Canada.

The correlation analysis resulted to be important since the main criterion to improve this crop is to select for reducing the time needed for harvesting. It could be done by either decreasing the time when the first flower opens until the opening of the fifth one (X1) or reducing the time since the first fruit was harvested until the harvest of the fifth one (X2). Unfortunately, we did not gather enough data, in Elora locality, to analyze X2, because some of the tomatillo landraces were too late. But, the data for $\mathrm{X} 1$ were complete, and it resulted that there is no correlation between X1 and the yield. Data in Chapingo were complete and showed that X1 and X2 were uncorrelated with yield. This could indicate that it would be better to select for earliness (less days from planting to flowering and fruiting) and for the yield in the same direction, especially if this crop is going to be cultivated under Ontario environment since its growth season is quite short. The total number of fruits (tnfr) and the average weight per fruit (awpfr) were highly, positively and significantly correlated with the yield. It opens another option to increase yield by selecting those landraces which have either the highest number or the biggest fruits. Absolute values of the correlation coefficients were higher in Elora than in Chapingo. It may suggest that selection in the former locality must be directed by using any trait evaluated, to increase yield indirectly; while in the later, selection must be restricted to use fruit harvest dates (frlh, fr5h), tnfr and awpfr.

Besides of our trials to cultivate tomatillo in a region colder than Mexico, other authors have also performed similar trials. Moriconi et al. (1990) cultivated this plant in Louisiana (U.S.A) and reported that tomatillo cropped in the field, gave the yield of $1.35 \mathrm{~kg} \cdot \mathrm{m}^{-2}$ while in Cucurova, Turkey some lines of tomatillo (Physalis ixocarpa Brot.) were grown under field conditions and yielded $2.05 \mathrm{~kg} \cdot \mathrm{m}^{-2}$, on average, during two consecutive years (Abak et al. 1994). In the former USSR tomatillo has been introduced and cultivated since 1926 with very outstanding results due to receiving some improved varieties, derived by mass and family selection, with enough earliness and high yield; for this reason this species could be cropped in the Kamchatka Peninsula, Primorskiy Kray, Yakut and Buriat regions, Omsk and Tomsk regions (all in Siberia) and also in northern regions of the European part of Russia (Medvedev 1958). Although, these comparisons seem to be not fully correct since tomatillo germplasm is not exactly the same, it could be inferred that Elora, Ontario, Canada, similarly like those numerous northern localities, is a good place to crop tomatillo.

\section{CONCLUSIONS}

Rendidora landrace accession 1 (Rendidora, CHF1-Chapingo) and accession 3 (Rendidora, PRONASE), and Manzano landrace accession 1 (Manzano NF 20 120) were the earliest and gave the highest yield in Elora, Ontario, Canada. It is remarkable that the same accessions yielded the best in Chapingo, in 
central Mexico. The yield of these accessions in both localities was statistically not different, thus tomatillo seems to be a good new crop for Ontario, Canada agriculture. However, some landraces like Salamanca and the very late Milpero are not suitable to Canada environmental conditions. Tomatillo yield was negatively correlated with the number of days since planting to flowering and harvest, but highly positively correlated with the average weight of fruit and total number of fruits - it indicates that it would be possible to develop tomatillo varieties with short life cycle and high yield by artificial selection. Tomatillo accessions in Elora did perform earlier than in Chapingo and have less fruits but of larger size.

\section{REFERENCES}

Abak K., Guler H.Y., Sari N., Paksoy M. 1994. Earliness and yield of Physalis (Physalis ixocarpa Brot. and Physalis peruviana L.) in greenhouse, low tunnel and open field. Acta Hort. 336: 301-306.

Bertram R.B. 1991. New Crops and the International Agricultural Research Centres. In: New crops. (J. Janick \& J.E. Simon, eds.) John Wiley and Sons, Inc. New York, USA.

Bukasov S.M. 1963. Las plantas cultivadas de México, Guatemala y Colombia. IICA. Zona Andina. Publicación miscelánea \# 20. 261 pp.

Cantwell M.J., Flores M.A. Trejo G. 1992. Developmental changes and postharvest physiology of tomatillo fruit (Physalis ixocarpa Brot.). Sci. Hort. 50: 59-70.

Cuartero J., Costa J., Palomares G., Nuez F., 1983. Comportamiento de Physalis en condiciones de cultivo del sureste español. Primer Congreso Nacional I: 161-164. Sociedad Española de Ciencias Hortícolas. Almería, España. [in Spanish]

Jankiewicz L.S., Borkowski J. 1990. The development of tomatillo (Physalis ixocarpa Brot.) in Polish conditions. II. Flowering and fruiting. Acta Agrobot. 43: 11-23.

Jenkins J.A. 1948. The origin of cultivated tomato. Economic Botany. 2: 379-392.

Kuehl R.O. 1994. Statistical principles of research design and analysis. Wadsworth Inc. Belmont, California, USA.

McCain R. 1991. Goldenberry, passion fruit and white sapote: potential fruits for cool subtropical areas. pp 479-486. In: New crops. (J. Janick \& J.E. Simon, eds.). John Wiley and Sons, Inc.; New York, USA.

Medvedev P.F. 1958. Fizalis-Physalis L. In: Flora of cultivated plants. Family Solanaceae. Brezhniev D.D. ed. State Agric. Publishing Office, Moscow. 20: 488-501.

Menzel M.Y. 1951. The cytotaxonomy and genetics of Physalis. Proc. Amer. Phil. Soc. 95: 132-183.

Montgomery D.C. 1991. Design and analysis of experiments. John Wiley and Sons, Inc.

Moriconi D.N., Rush M.C., Flores H. 1990. Tomatillo: a potential vegetable crop for Louisiana. pp. 407-413. In: Advances in new crops. (Janick J., Simon J.E. eds.). Timber Press, Portland, Oregon. USA.

Mulato-Brito J., Jankiewicz L.S., Fernández-Orduña V.M., Cartujano-Escobar F., Serrano-Covarrubias L.M. 1985. Growth, fructification and plastochron index of different branches in the crown of the husk tomato (Physalis ixocarpa Brot.). Acta Soc. Bot. Pol. 54:195-206.

Peña-Lomelí A., Márquez-Sánchez F. 1990. Mejoramiento genético del tomate de cáscara (Physalis ixocarpa Brot.). Rev. Chapingo. Vol 71,72: 84-85. Chapingo, México. 
Peron J.Y., Demaure E., Haunetel C. 1989. Possibilities of tropical solanaecea and cucurbitaceae introduction in France. In: First international symposium on diversification of vegetable crops. Wageningen (Netherlands). ISHS. p. 179-186.

Porcelli S., Proto M. 1991. Physalis ixocarpa Brot, a promising new crop. SementiElette. 37(6): 27-31.

Rexen F. 1993. The development of new crops: EC projects and prospects. In: New Crops for Temperate Regions. (K.R.M. Anthony, J. Meadley \& G. Robbelen, eds). Chapman and Hall. New York, USA.

Sas-Stat. 1985. Guide for personal computers. Sas Institute Inc., N.C. USA.

\section{OCENA FORM HODOWLANYCH MIECHUNKI (PHYSALIS IXOCARPA BROT.) UPRAWIANYCH W WARUNKACH ŚRODOWISKA STANU ONTARIO W KANADZIE I CHAPINGO W MEKSYKU}

\section{Streszczenie}

Porównano 5 odmian lokalnych miechunki pomidorowej, w tym 13 form hodowlanych, w warunkach stanu Ontario w Kanadzie oraz Chapingo w centralnym Meksyku. Wzięto pod uwagę następujące cechy roślin: początek kwitnienia i owocowania, całkowitą liczbę zebranych owoców i plon. Liczbę dni do kwitnienia czy owocowania liczono od chwili posadzenia roślin. W obu miejscowościach formy 1 i 3 odmiany Rendidora, jak również forma 1 odmiany Manzano były najwcześniejsze i plonowały najlepiej. W Chapingo forma 1 odmiany Rendidora dała plon owoców prawie $4 \mathrm{~kg} \cdot \mathrm{m}^{-2}$, w miejscowości Elora w Kanadzie ta forma również była najlepsza i dała prawie $30 \mathrm{~kg} \cdot \mathrm{m}^{-2} . \mathrm{Na}$ ogół wszystkie badane formy owocowały wcześniej w Elorze niż w Chapingo. Plonowanie $\mathrm{w}$ obu miejscowościach było podobne, $\mathrm{z}$ wyjątkiem odmiany lokalnej Milpero, wyraźnie niedostosowanej do warunków Kanady. Miechunka pomidorowa może być więc obiecującą nową rośliną uprawną w stanie Ontario w Kanadzie. Plon był skorelowany ujemnie, w sposób istotny z liczbą dni do kwitnienia i zbioru. Świadczyłoby to, że wyhodowanie wczesnych, wysoce produktywnych odmian jest w pełni możliwe. 